\title{
INTERFACE
}

Sociologias, Porto Alegre, ano 7, no 14, jun/dez 2005, p. 504-508

\section{Falecimento de Octávio lanni: a sociologia perde um mestre}

MARIA STELA GROSSI PORTO

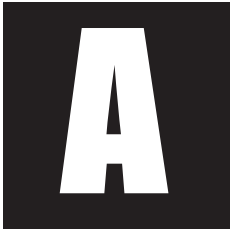

Sociedade Brasileira de Sociologia - SBS - une-se, entristecida, ao coro de vozes que, de pontos distintos e distantes do País, vem a público expressar seu sentimento e pesar pela morte do sociólogo Octávio lanni, ocorrido a 04 de abril de 2004, em S. Paulo.

Muitos se manifestaram desde então, lembrando a importância do professor lanni como formador de gerações de sociólogos, como analista sensível da realidade brasileira, cuja obra, importante sobretudo pela relevância e diversidade dos temas tratados, é fonte incontornável de consulta para quem pretende aprofundar-se no conhecimento dessa realidade e da sociologia que a ela se dedica.

Concordando com o tom destes pronunciamentos, gostaria de lembrar também uma outra contribuição fundamental deixada pelo professor e pesquisador Octávio lanni. Refiro-me à sua participação no processo de construção institucional do campo científico da sociologia, tarefa que ele realizou com a convicção de quem faz da sociologia profissão e vocação. Com profundo sentido de profissionalismo e agudo senso crítico, dedicou

* Maria Stela Grossi Porto é presidente da Sociedade Brasileira de Sociologia - SBS e Professora do Departamento de Sociologia 
sua vida ao ofício de sociólogo e foi agente ativo e eficaz de institucionalização e consolidação da sociologia no/do Brasil. Preocupado em conhecer e em fazer conhecer a realidade de seu país, Octávio lanni projetou a sociologia aqui produzida (hesito sempre em falar de uma sociologia brasileira, pois acredito que nacionais são os temas de que trata a disciplina e não seu arcabouço teórico-metodológico), legitimando e dando visibilidade a esse campo do saber, não apenas dentro como também fora do país. Nas distintas instituições de ensino e pesquisa em que atuou no exterior, exercendo a atividade docente, contribuiu para promover, além fronteiras, o reconhecimento internacional da sociologia feita no Brasil. O professor Octávio lanni foi sociólogo em "tempo integral"; isso implica dizer que, independentemente do tema abordado, pensava-o sociologicamente. Dialogou com a sociologia clássica e contemporânea, com a familiaridade e a criatividade dos que sabem traduzir esse diálogo em produção de novos conhecimentos.Visitou e revisitou clássicos e contemporâneos com profundo conhecimento do solo teórico no qual pisavam e no qual ele pisava, fazendo do mergulho na tradição sociológica, que tão bem dominava, a ponte para a inovação, e da prática sociológica um instrumento de mudança social.

Recentemente, e ainda sem saber das precárias condições de saúde do professor lanni, dizia a alguns alunos que, se me fosse solicitado apontar rapidamente uma característica desse sociólogo, não hesitaria em dizer que sempre me impressionei, para não dizer que sempre me emocionei, com a maneira intrépida com a qual enfrentava os desafios teóricos. Dizia isso referindo-me ao fato de que, em uma etapa da vida na qual alguns intelectuais passam a viver do que fizeram e a usufruir, legitimamente diga-se de passagem, da obra já construída, o professor Octávio lanni, munido de coragem, espírito de luta, disposição para o trabalho de recomeçar e, instigado pelo que, no campo das ciências sociais, ficou conhecido como 'a 
crise dos paradigmas', mergulhou em novas leituras, em novas pesquisas, abrindo espaço a outras vertentes de sua reflexão, e à incorporação de outros problemas ao vasto campo de pesquisas a que se dedicou. Foi assim que incorporou a seu campo de interesses teóricos o tema da globalização. Tema que, uma vez mais, enfrentou a partir de indagações iniciais votadas à compreensão da realidade brasileira. Em suas análises transparecia o estado permanente de inquietação que é matéria-prima do processo de produção de conhecimento; conhecimento que, no seu caso, poder-se-ia dizer engajado; sem jamais ser outra coisa que sociólogo, sem nunca fazer outra coisa que não sociologia, Octávio lanni cumpriu aquele objetivo que deu sentido à obra dos pais fundadores, qual seja o de perseguir, em seu labor teórico, algum tipo de intenção prática.

Mesmo os que não comungam integralmente sua abordagem teórica, estão de acordo em ressaltar o caráter eminentemente sociológico de sua produção. Apontam também, dentre as características mais marcantes de seu perfil intelectual, que o professor lanni moveu-se sempre no campo científico, fazendo da 'imaginação sociológica' e da vontade de ir mais além os objetivos primeiros para pensar e perseguir uma sociologia voltada à transformação social. Essa característica fez do professor Octávio lanni um radical, se por radical entendermos alguém fiel a seus ideais e coerente com suas concepções acerca da ciência e do papel do cientista. Radical também na busca do conhecimento e na certeza da responsabilidade social, fruto desse conhecimento. E se é verdade, como já afirmou alguém, que a radicalidade é um dos caminhos possíveis para a felicidade, o prof. lanni deve ter sido um homem feliz.

Ao aliar coragem no enfrentamento dos desafios teóricos impostos pela realidade (desafios que nem todos aceitam) à personalidade radical, tal como definida acima, Otávio lanni cunhou também um outro traço marcante de sua personalidade intelectual: assumiu em sua prática sociológica a ca- 
racterística weberiana da sociologia como a 'ciência da eterna juventude' Ao fazê-lo, incorporou no praticante a qualidade que Weber reservava à ciência. A garra para o enfrentamento dos desafios, a capacidade de luta e de indignação faziam dele um sociólogo eternamente jovem, independentemente do passar dos anos. E por isso, dizem os que mais recentemente privavam de sua companhia como colega de trabalho na UNICAMP, mesmo com a saúde debilitada, o professor se manteve jovem aos 77 nos e continuava pondo em prática seu ofício de sociólogo, até pouco antes de ser compulsoriamente paralisado pela morte.

Durante a gestão do Prof. César Barreira, a Sociedade Brasileira de Sociologia teve o privilégio de homenagear em vida o professor Octávio lanni, ao inclúi-lo na primeira turma de contemplados com o Prêmio Florestan Fernandes, entregue no último congresso da sociedade, realizado em Campinas em 2003. Naquele momento ele foi lembrado e homenageado como referência da sociologia e das ciências sociais, com uma obra que abarca uma multiplicidade de aspectos da realidade, abrangendo da questão racial às análises sobre o Estado e a Sociedade, das questões da cultura àquelas voltadas ao problema da escravidão e, por fim, aos estudos sobre globalização. Por tudo isso, lanni foi uma presença constante, crítica, intrigante e instigante não apenas no Brasil, mas na América Latina e em outras partes do Planeta. Seus estudos combinam uma rigorosa pesquisa empírica com uma criativa perspectiva teórica.

Reavivamos o exemplo do mestre e registramos a homenagem e o carinho da Sociedade Brasileira de Sociologia ao professor Octávio lanni, com toda nossa saudade.

Recebido: 21/02/2005

Aceite final: 24/03/2005 
Sociologias, Porto Alegre, ano 7, no 14, jun/dez 2005, p. 504-508

\section{Resumo}

O artigo é uma homenagem que, em nome da Sociedade Brasileira de Sociologia - SBS - foi prestada ao Prof. lanni. O texto lembra a importância do Prof. lanni, como formador de gerações de sociólogos e como analista sensível da realidade brasileira mas insiste, sobretudo, na contribuição fundamental por ele deixada, no que se refere à participação no processo de construção institucional do campo científico da sociologia, tarefa realizada com a convicção e o profissionalismo de quem dedicou a vida ao ofício de sociólogo, como agente ativo e eficaz da institucionalização e da consolidação da sociologia no/do Brasil. Palavras-chave: Octavio lanni, Sociologia, Ensino e Pesquisa. 


\section{The passing of Octávio lanni: sociology loses a master}

\section{Maria Stela Grossi Porto}

The paper is a tribute to Professor lanni on behalf of the Brazilian Sociology Society - SBS. The text underlines lanni's importance for the formation of generations of sociologists and as a sensitive observer of Brazilian reality. However it stresses his fundamental legacy for the process of institutional construction of the scientific field of sociology - a task he carried out with the conviction and professionalism of a life dedicated to the trade of sociologists as active and effective agents of institutionalization and consolidation of sociology in and of Brazil.

Key words: Octavio lanni, Sociology, Teaching and Research 